\title{
References
}

Bøggild, O. B. 1953: The mineralogy of Greenland. Meddr Grønland 149,3, $442 \mathrm{pp}$.

Chinner, G. A. \& Schairer, J. F. 1962: The join $\mathrm{Ca}_{3} \mathrm{Al}_{2} \mathrm{Si}_{3} \mathrm{O}_{12}-\mathrm{Mg}_{3} \mathrm{Al}_{2} \mathrm{Si}_{3} \mathrm{O}_{12}$ and its bearing on the system $\mathrm{CaO}-\mathrm{MgO}-\mathrm{Al}_{2} \mathrm{O}_{3}-\mathrm{SiO}_{2}$ at atmospheric pressure. Am. J. Sci. 260, 611-634.

Haggerty, S. E. 1972: Apollo 14: Subsolidus reduction and compositional variations of spinels. Geochim. cosmochim. Acta, supp. 3, 1, 305-332.

Hald, N. \& Pedersen, A. K. in press: Lithostratigraphy of the early Tertiary volcanic rocks of central West Greenland. Rapp. Gronlands geol. Unders. 69, 17-24.

Henderson, G. 1969: Oil and gas prospects in the Cretaceous-Tertiary basin of West Greenland. Rapp. Gronlands geol. Unders. 22, 63 pp.

Melson, W. G. \& Switzer, G. 1966: Plagioclase-spinel-graphite xenoliths in metallic ironbearing basalts, Disko Island, Greenland. Am. Miner. 51, 664-676.

O'Hara, M. J. 1968: The bearing of phase equilibria studies in synthetic and natural systems on the origin and evolution of basic and ultrabasic rocks. Earth-Sci. Rev. 4, 69-133.

Pauly, H. 1969: White cast iron with cohenite, schreibersite and sulphides from Tertiary basalts on Disko, Greenland. Meddr. dansk geol. Foren. 19, 8-26.

Pedersen, A. K. in press: New mapping in north-western Disko, 1972. Rapp. Grønlands geol. Unders. 69, 25-32.

Rosenkrantz, A. \& Pulvertaft, T. C. R. 1969: Cretaceous-Tertiary stratigraphy and tectonics in northern West Greenland. Mem. Am. Ass. Petrol. Geol. 12, 883-898.

Steenstrup, K. J. V. 1882a: Om Forekomsten af Nikkeljern med Widmannstättenske Figurer i Basalten i Nord-Grønland. Meddr Grønland 4, 113-132.

Steenstrup, K. J. V. 1882b: Om Forekomsten af Forsteninger i de kulf $\varnothing$ rende Dannelser i Nord-Grønland. Meddr Grønland 5, 43-77.

Törnebohm, A. E. 1878: Über die eisenführende Gesteine von Oifak und Assuk in Grönland. Bih. K. svenska VetenskAkad. Handl. 4(10), 1-22.

Mineralogisk Museum, $\emptyset$ ster Voldgade 5-7, 1350 Copenhagen $K$.

\section{High temperature pyrrhotite and telluric iron mineralisations in western Disko, central West Greenland}

\section{Finn Ulff-Mфller}

The main purpose of the summer field work was to carry out a detailed investigation of the high temperature nickeliferous pyrrhotite and telluric iron mineralisation which occurs in the subvolcanic intrusions of the Hammers Dal Complex (Pedersen, this report, and in press), and to search for other occurrences with an economic evaluation in view.

The dyke-like intrusions are mainly found in gorges in the south facing slope of the E-W trending Hammers Dal, about $10 \mathrm{~km}$ from the west coast of Disko. They are exposed only in the upper $400 \mathrm{~m}$ of the Rinks Dal Member. The depth of the intrusions was thus $400-500 \mathrm{~m}$ below the palaeosurface, marked by the weakly contaminated basalts and more strongly contaminated 'andesites' of the Niaqússat Member which are 
considered to be the extrusive equivalents of the intrusions. The magma seems to have intruded along a joint zone dipping about $70^{\circ} \mathrm{WSW}$ forming pipes or dyke-like bodies plunging gently NNW.

\section{Magma and mineralisation}

The intruding magma was composite, including a basaltic and a more contaminated, silicious melt. According to Pedersen (in press) it was formed by contamination of an olivine tholeiitic magma with Cretaceous and Tertiary sandstones and shales rich in sulphur and organic compounds.

The fine to medium-grained dolerite, representing the original basaltic magma, contains xenoliths of baked shale and sandstone concentrated under the roof of the intrusions and underneath overhanging projections of the wallrock. An extreme cumulation of light sandstone and shale xenoliths took place under the roof of the sill, where they form a densely packed layer 2-3 $\mathrm{m}$ thick with a subordinate matrix of dolerite. The heavy xenoliths concentrated at the bottom of the intrusions and on step-like shelves in the eastern contact, together with coarse aggregates and single crystals of skeletal olivine.

In this marginal dolerite about $0.5-1.0 \mathrm{~m}$ above the contact cumulate zones $0.5-1.5$ $\mathrm{m}$ thick of telluric iron and cupriferous and nickeliferous pyrrhotite were formed both at the bottom of the intrusions and on the shelves. In the lower part of the cumulate zones bodies of iron intergrown with pyrrhotite* forming 1-2 cm long ellipsoids occur in a matrix of dolerite and disseminated sulphides. Some ellipsoids of pure pyrrhotite have also been found. The amount of pyrrhotite decreases upwards within a cumulate zone and the iron bodies become coarser, forming up to $5 \mathrm{~cm}$ long spongy bodies passing into a matrix of nearly pure, or faintly sulphide disseminated dolerite. Laterally the cumulate zones wedge out near the edges of the shelves and, where the dip of the contacts exceeds about $70^{\circ}$, terminate in a dolerite rich in disseminated sulphides. The placing of the cumulate zones indicates that the intrusion took place before the faulting and tilting of the lavas. In a sill $0.5 \mathrm{~km}$ to the east, the cumulate zone is continuous throughout and varies in thickness between 0.5 and $0.8 \mathrm{~m}$. The cumulate seems to closely resemble the cumulate zones in the dyke-like intrusions. Between the dolerite and the contact a $20-30 \mathrm{~cm}$ thick layer of a feldsparphyric, grey rock with spherical and 'drawn out' bodies of pyrrhotite intergrown with fine lamellea and vermicular bodies of a black, glassy mineral occurs. This rock is believed to be a partially melted and recrystallised tuff. In one place, underneath the layer of feldsparphyric rock, a heavily mineralised layer less than $0.5 \mathrm{~m}$ thick, believed to be mineralised scoria, occurs where the sill cuts through the scoriaceous top of a lava at a low angle.

The central parts of the intrusions consist of 'andesitic' rocks of two or three types which grade into the marginal dolerite through narrow transitional zones. The transition zone is $5-20 \mathrm{~cm}$ wide in the upper part of the sill. There seems to be a much more complete transition in the lower part of the sill where a distinct $5 \mathrm{~cm}$ wide zone, in which bodies of branching iron are concentrated, occurs at the junction.

The central 'andesitic' rocks are all characterised by a relatively large content of 
sediment xenoliths ranging in size from a few millimetres to $20 \mathrm{~cm}$. These occur together with up to $2 \mathrm{~cm}$ long prismatic phenocrysts of orthopyroxene and small globules of iron. The globules range in size from $0.5-10 \mathrm{~mm}$ and are rimmed with less than $1 \mathrm{~mm}$ of the iron mineral troilite. The smaller globules are spherical, probably due to surface tension in the molten stage, whereas larger ones are elongate or amoeboid. Except for the iron globules, which may show a very weak tendency for gravitational concentration, phenocrysts and xenoliths occur unevenly distributed in a matrix of a fine-grained, globular-textured rock similar to that found at Asuk (Pedersen, 1973).

The different types of 'andesitic' core rocks can be distinguished in the field by their joint patterns and by differences in their phenocryst and xenolith content. However, they are all characterised by a distinct, tar-like smell from fresh fracture surfaces.

An additional intrusion occurs to the west. Large amounts of 'andesitic' loose blocks in solifluction debris along a fracture zone on the plateau south of Hammers Dal indicate that the intrusion occurs along a NNW-SSE trending zone for about $7 \mathrm{~km}$.

Near the settlement Diskofjord a dyke of weakly contaminated basalt was found, probably corresponding to that found by K. J. V. Steenstrup and known from specimens in the collections of the Mineralogical Museum, Copenhagen. At the west dyke contact a body $30 \mathrm{~cm}$ across of massive pyrrhotite intergrown with coarse dendritic black glassy material containing fine needles of cohenite was found. Near the east contact a subvertical zone with branching iron bodies was observed.

*Added in proof. Now inverted to the low temperature polymorph, troilite.

\section{References}

Pedersen, A. K. 1973: Report on field work along the north coast of Disko, 1971. Rapp. Gronlands geol. Unders. 53, 19-27.

Pedersen, A. K. in press: New mapping in north-western Disko, 1972. Rapp. Gronlands geol. Unders. 69, 25-32.

Mineralogisk Museum, $\emptyset$ ster Voldgade 5-7, 1350 Copenhagen $K$.

\section{Field mapping of the pre-3760 m.y. old supracrustal rocks of the Isua area, southern West Greenland}

\section{Jan H. Allaart}

The first of a two-summer mapping programme on the Isua supracrustal rocks was undertaken as part of a larger mapping project aimed at the completion of the 1:500 000 map sheet Søndre Strømfjord - Frederikshåb Isblink.

The Isua supracrustal belt with its major occurrence of banded ironstone was dis- 